\title{
THE INFLUENCE OF LEADERSHIP, MOTIVATION AND DISCIPLINE ON EMPLOYEES 'PERFORMANCE OF NATIONAL UNITARY AGENCIES DISTRICT SORONG
}

\author{
Kamaluddin ${ }^{1}$ \\ (1 Lecturer in Muhammadiyah University Of Sorong) \\ e-mail : kamaluddinr@yahoo.com \\ Abstract
}

This study aims to determine the influence of leadership factors, motivation and discipline on the performance of employees of the National Unity Board of Sorong Regency. The method of data processing using multiple linear regressions and to test the effect simultaneously using $\mathrm{F}$ test, while to test the influence of partially and dominant use T test. Object of research is all employees of National Unity Board of Sorong Regency through 50 respondents as sample by using total sampling. Research data is sourced from data obtained from questionnaire to respondent. The result of the research showed that leadership, discipline and motivation have significant influence and motivation variable have dominant influence to the work performance on the employee performance of National Unity Agency of Sorong Regency Government.

Keyword: leadership, motivation, performance

\section{A. Background}

In improving adaptation to changes in community demands, organizational change towards a more advanced one should always be pursued with the requirement to answer the needs of changes and improvements that are relevant and desired by the community (customer oriented), thus requiring active involvement of the community in preparing the plan and implementation of the change (Thoha: 1993). Therefore, the changes not only cover the physical aspect but also on aspects of culture and organization's behavior.

Accordingly, organizations that are insensitive to the demands of change lead to the possibility of the organization becoming infected with a disease called organizational pathologies. If the condition is left, it will hinder and hinder the achievement of organizational goals (Wahyudi: 1997). Declining productivity, reduced absenteeism and work discipline, resource wastage, long task completion times and other negative symptoms are indications in the organization that something is wrong. This phenomenon sometimes seems clear and vice versa it is largely invisible so they are not aware or able to identify what the real problem is going on within an organization.

If the condition persists continuously, then it can be assured that the performance of the organization will be disrupted and unable to show the level of productivity ideally (Thoha: 1993). Therefore, an initial intervention known as diagnostic term is necessary, which is defined as the whole process that includes collecting information related to the problem, such as how the organization should function to analyze the information and make conclusions to make changes and improvements.

All that is pursued in principle is aimed to achieve the main objectives of improving organizational performance optimally, effectively and efficiently. To determine how far the level of success of an organization, especially private organizations (organization of production) is to see the level of efficiency and effectiveness of its business. But to see the success of public organizations or government benchmarks are not as easy as in private organizations. This is because public organization owned by the government, still not right because the purpose of this organization is still vague and multidimensional (Dwiyanto: 1995). Therefore, to achieve the goal of performance improvement, especially for government organizations, it is determined by the 
leadership that not only have the ability but capable of having strong support and acceptable by all organizational components.

In essence, the members of organization consisting of various levels and positions are influenced by the existence of driving factors that can improve performance in production. So in improving the motivation of all employees, then the effort should be comprehensive (integrated) covering internal and external aspects as well as physical and nonphysical.

In addition, the improvement of organization's performance is also determined by other technical factors such as timeliness, procedures and quality of products produced in accordance with the planned quality standards. Therefore, the obedience and loyalty of all components of the organization towards the achievement of goals has become an unavoidable requirement. Thus, the discipline of employees as part of the overall organizational system greatly determines the level of performance achieved by an organization.

However, in doing organization changing according with the demands of society that led to decision-making is something that is difficult to do because it is difficult to identify variables that have an influence on organizational changes. Therefore, in this paper examines the variables of leadership, motivation and discipline simultaneously, partial and dominant influence on employment performance of employees at the National Unity Board (Kesbang) Sorong District Government.

\section{B. Leadership}

According to Malayu (2002), leader and leadership is leader (leader = head) is someone who uses authority and leadership, directing subordinates to do some work in achieving organizational goals. While the leadership (leadership) set by a manager in the organization can create harmonious integration and encourage employee's passion to achieve maximum goals.

Leader is a person who has special advantages in influencing others to jointly perform certain activities in achieving a goal (Kartono: 1988). So according Siagian (1983) there are certain qualities that characterize the leader that has integrity, enthusiasm, calm, firm and fair. Therefore, leaders emphasize more than the aspect of influence (influence). Correspondingly, one can be called a leader if it can influence others to achieve a certain goal, even though there is no formal tie in the organization (Tjokroamidjojo, 1985).

On the other hand, that the term leadership is a process of one's activities in leading, guiding, influencing, controlling the thoughts and behavior of others in order to achieve certain goals (Effendy, 1986). So Salusu (1996), personally said that leadership is a force that drives activities. Therefore, it is believed that in each person there is potential for leadership, but there are not people realize it. Explicitly that each person has the potential to become a leader but the limited opportunity or opportunity to develop potential energy into the form of actual activity

Implementation of leadership should be able to cultivate trust, participation, loyalty and internal motivation of subordinates in a persuasive way because leadership is the way a leader influences the behavior of subordinates in order to work together and work productively to achieve organizational goals. Thus, it can be simply understood that the leader is focused on the personality of the subject who has certain advantages over the other person. While the leadership is more defined as the ability of a leader and his way and style in doing his role as a leader.

Sedangkan kepemimpinan lebih diartikan sebagai kemampuan seorang pemimpin beserta cara dan gayanya dalam melaksanakan perannya sebagai seorang pemimpin.

Nevertheless, there are various models of leadership according to Malayu (2002), known by the concept of situational leadership that is the selection and application of leadership models in accordance with varied situations. So it can be understood that none of the best ways to influence others depends on the degree of readiness of the person to be affected. 


\section{Work Motivation}

The scope of motivation focuses on how to direct the power and potential of subordinates in order to cooperate productively and successfully achieve and realize the goals that have been determined (Malayu, 2002). Motivation is the provision of a driving force that creates a person's passion for them to work effectively and integrate with every effort to achieve satisfaction. So that satisfaction covers the aspect of satisfaction or goals of the organization and individuals simultaneously. Accordingly, Edwin B. Flippo (2002) says "direction or motivation is essence, it is a skill in aligning employee and organization interest so that behavior result in achievement of employee want simultaneously with attainment or organizational objective".

Everyone will be happy and willing to work if they have enough reason why and for what it should be done. The reasons that encourage people to do something are known by the term by motive. Directly the whole of human behavior is always related to the necessities of life as expressed by Abraham Maslow (1987) in the "hierarchy of needs". There are two main principles of Maslow's view that needs can arranged in the hierarchy of the lowest needs to the highest needs, and an already satisfied need will cease to be the primary motivator of behavior. So humans will be encouraged to meet the most powerful needs of time, circumstances and experiences that follow a hierarchy. Thus, it can be explained that motivation is a stimulus or stimulus that someone wants to do something to fulfill their needs.

Motivation is essential in order to move people toward a defined goal. Because every leader should be have the ability to motivate their subordinates so that they can participate in supporting the achievement of common goals. Meanwhile, Herzberg (1987) says there are two different factors touching human behavior in work that is Hygiene factor that touches through a sense of satisfaction and dissatisfaction in his work, because it concerns his work environment, and motivator factors that touch humans through the pleasure of working and can increase or decrease work productivity.

\section{Work Discipline}

Discipline is an exercise or education of modesty and character development (Moekijat, 1999). Explicitly emphasizes everyone to develop appropriate attitudes and behaviors in ethical and moral dimensions through educational and training approaches. According to Sumedi (1985) train and educate people against the rules so that there is compliance in order to run orderly and regularly within the organization. An orderly condition where the persons who joint in organization are existed the rules. Discipline can be seen not only in the form of obedience of people to the rules, but the obedience and loyalty is also carried out with pleasure and not because of coercion or pressure

Discipline emphasizes obedience that is impersonal in nature and does not use feelings or self-interest calculations. Thus, discipline is the only way or means to maintain existence or existence of the organization. Cooperation has been established and has been followed by the division of labor, authority and responsibility, then the cooperation must run without having to be accompanied by the intervention of the authority of the other party. So each member holds the established rules without leaving the awareness that each is a component or part of a complete system.

In the context of formal legalistic, discipline is intended as a rule that must be done firmly and strictly. On the other hand, discipline requires the existence of sanctions in the form of certainty or necessity of imposed absolute punishment. So that a good discipline reflects the magnitude of one's responsibility for the task assigned to him. This encourages the passion of work, the spirit of work and the realization of organizational goals. Thus, the discipline is the key to realize of organization's goals. 


\section{E. Work Achievement}

Bernadin and Russell (1997) say that the output resulted from the function of a particular occupation or activity during a given period. While productivity is the ratio between the results of costs and productivity is more emphasis on efficiency. So it can be understood that work performance has a varied size because the results (output) generated between one part with the other can be different. Therefore, work performance is an output, given by employees to the organization so that in this sense work performance is not only the amount of goods or work that can be completed alone, but also can mean ideas or ideas put forward to the organization in order to improve overall results.

Work achievement is a result or a close relationship with productivity because it is an indicator in determining how efforts to achieve high levels of productivity within an organization (Sedarmayanti, 2001). Thus, it appears that performance measurement results cover a wider range of fields, ranging from activity activities, development programs to policy fields.

In relation to that, performance or performance is always associated with two factors namely the factor of willingness or motivation and ability factor in implementing it. To find out how much work performance, then the measurement is useful to determine the appropriate rewards, and to provide motivation in improving job performance. So Henry Simamora (2001) stated that job performance measurement can be categorized into three approaches, namely result based performance appraisal, behavior based performance appraisal, judgment based performance appraisal. Therefore, in this study tend to use judgment based performance appraisal.

\section{F. Method}

The population of this study is all employees of the National Unity Board of Sorong District Government and the number of samples is 50 people by using total sampling technique with detail sample as follow:

Data Respondent According Section

\begin{tabular}{|c|l|c|}
\hline No & Klasificasion /Section & Amount \\
\hline 1 & Section IV & 1 \\
2 & Section III & 15 \\
3 & Section II & 25 \\
4 & Honorary & 9 \\
\hline & Total & $\mathbf{5 0}$ \\
\hline
\end{tabular}

Validity test is done by using criteria taken from the measuring instrument itself by using correlating between the score of the item with the total score (whole item) called the validity of items using internal criteria. The correlation technique used in the validity test is Product Moment correlation technique from Pearson (1994) as follows:

$$
r X Y=\frac{\sum X Y-\left(\sum X\right)\left(\sum Y\right) / n}{\sqrt{\left[\sum X^{2}-\left(\sum X\right)^{2} / n\right]\left[\sum Y^{2}-\left(\sum X\right)^{2} / n\right]}}
$$

Keterangan : 
rXY : $\quad$ Coofisien correlasion Product Momment

$\sum X: \quad$ Total score of independent variable $(\mathrm{X})$

$\sum Y: \quad$ Total Score of dependent variable (Y)

$\sum X Y: \quad$ Total multiplication score of variable $\mathrm{X}$ and $\mathrm{Y}$

$\mathrm{N} \quad$ : Total Respondent

Furthermore, the technique used to perform reliability test with Alpha Cronbach scale by grouping items into two or several parts as follows:

$$
=\left[\frac{K}{k-1}\right]\left[1 \frac{\sum S j^{2}}{S x^{2}}\right]
$$

Keterangan :

$\mathrm{K}=$ The number of test sections

$\mathrm{Sj}^{2}=\quad$ Variable section $\mathrm{j}(\mathrm{j}=1,2, \ldots \mathrm{k})$

$\mathrm{Sx}^{2}=\quad$ Variable score test

\section{Hypothesis testing}

To test the validity of hypothesis, this research used statistical analysis, include:

\section{The First Hypothesis Testing}

Testing the first hypothesis is done through simultaneous test with $\mathrm{F}$ test. This test is used to determine whether all independent variables simultaneously have a significant effect on the dependent variable. Testing is done by comparing the value of $\mathrm{F}$ count with $\mathrm{F}$ table at $5 \%$ error rate. If the value of $\mathrm{F}$ count $\mathrm{F}$ table means that the independent variable simultaneously gives a meaningful influence of all independent variables on the dependent variable. The F Test step is:

1. Determining the research hypothesis

2. Testing critheria at the significant level $0,05(5 \%)$

a. If $\mathrm{F}_{\text {count }} \leq \mathrm{F}_{\text {table }}, \mathrm{H}_{\mathrm{o}}$ accepted or rejected $\mathrm{H}_{\mathrm{a}}$

b. If $\mathrm{F}_{\text {count }} \geq \mathrm{F}_{\text {table, }} \mathrm{H}_{\mathrm{o}}$ rejected or accepted $\mathrm{H}_{\mathrm{a}}$

\section{The second hypothesis testing}

The second hypothesis testing is done by using $t$ test (partial test) which is used to know the partially significant influence of the independent variable to the dependent variable. Testing is done by comparing between $t_{\text {count }}$ of each independent variable with $t_{\text {table }}$ at $5 \%$ error degree. If $t_{\text {count }} \geq t_{\text {table }}$ each free variable $(X 1, X 2, X 3)$ gives a partially significant effect on the dependent variable $(\mathrm{Y})$. As for the criteria of hypothesis test are:

$$
\begin{aligned}
& \text { H O }=\text { accepted if } t_{\text {count }} \leq t_{\text {table }} \\
& \text { H O }=\text { rejected if } t_{\text {count }} \geq t_{\text {table }}
\end{aligned}
$$

\section{The third hypothesis testing}

The third hypothesis testing is done by interpretation of Standardized Beta coefficient or partial $\mathrm{r} 2$ based on $\mathrm{T}$ test result, to know the magnitude of the influence of each independent 
variable to the dependent variable, done by comparing the value of Standardized Beta coefficient or partial $\mathrm{r} 2$ between each independent variable at $5 \%$ error rate. The independent variable that has the value of standardized coefficient Beta or $\mathrm{r} 2$ largest is the dominant variable affect the dependent variable.

\section{G. Finding}

\section{Verification and discussion of the first hypothesis}

According to the first hypothesis that the writer proposed that the factor of leadership, motivation, discipline simultaneously affect the performance of employees of the National Unity Board of Government of Sorong Regency, then to test the significance of the hypothesis is used F-Test with procedures and criteria as follows:

a. Formulation of hypothesis statistic:

Ho: $\mathrm{R}^{2}=0$, It means that the factors of leadership, motivation, discipline simultaneously have not effect toward work achievement of employees on the National Unity Board of the government of Sorong Regency

Ha: $\mathrm{R}^{2}>=0$, It means that the factors of leadership, motivation, discipline simultaneously have effect toward work achievement of the Unitary State Agency of Government of Sorong regency.

b. Calculation of Critical value F:

The critical value of $F(\alpha, k-1, n-k)$ where $k=3$ and $n=50$, then $F(0.05,2,47)=3,200$. If $F$ count $<3,200$, it means Ho "is accepted" or Ha "rejected". Based on the calculation of F-count $=14,497$ and F-table $=3,200$ or F-arithmetic $>$ F-table and Sig $<0.05$ it means Ho "rejected" or Ha "accepted"

\section{c. Normal Curve Hypothesis Testing}

The normal curve of the simultaneous hypothesis test is presented in the following figure:

Figure

Normal Curve of Simultaneous Hypothesis Test

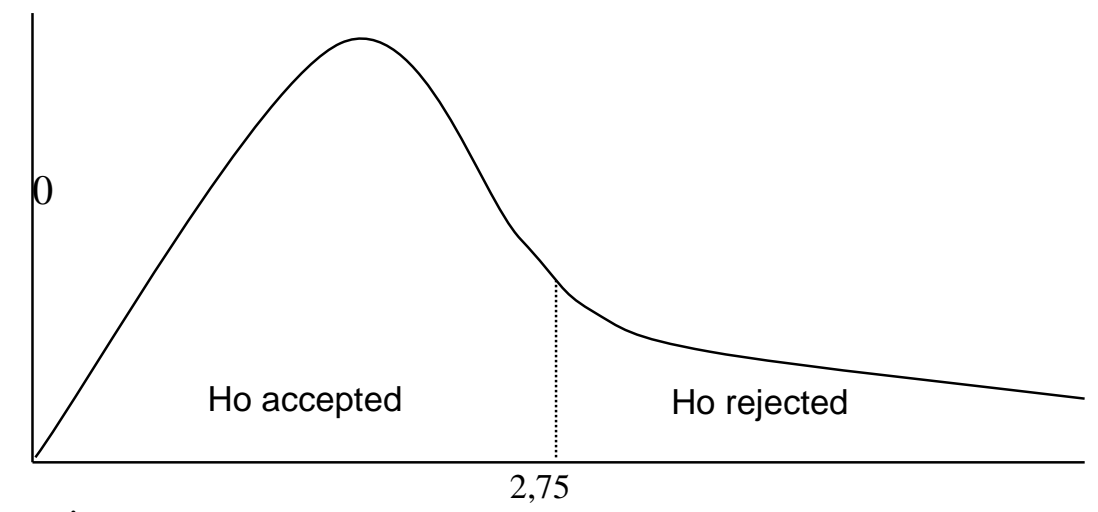

d. Discussion 
With the rejection of Hypothesis Zero (Ho) and acceptance of Alternative Hypothesis (Ha), it means that the factors of leadership, motivation and discipline simultaneously have a significant effect on the performance of employees of the National Unity Board of Sorong. The results of this analysis shows that employee performance has increased when simultaneously influenced by leadership factors, motivation and discipline that exist in the work environment. Thus, if the simultaneous independent variable in this study if really considered, it will trigger employees to improve work achievement.

\section{Verification and Discussion the second hypothesis}

According with the second hypothesis that the factors of leadership, motivation, discipline partially affect the performance of employees of the Board of National Unity Government of Sorong regency, then to test the significance of the hypothesis is partially verification with the tTest procedures and criteria as follows:

\section{Test the influence of leadership factors on employee performance}

a. Formulate statistical hypothesis

Ho: $b_{1}=0$, it means that the leadership factor partially has no effect on the work achievement of the employees on the National Unity Board of the government of Sorong Regency

Ha: $b_{1} \neq 0$, it means that the leadership factor partially affect the work performance of National Unity Agency of government of Sorong Regency.

b. Determining of critical $\mathrm{T}$ values

The critical value $\mathrm{t}(\alpha, \mathrm{n}-\mathrm{k})$ where $\mathrm{k}=3$ and $\mathrm{n}=50$, and $\alpha=5 \%$, then $\mathrm{t}(0.025,47)=2.010$. If $-2,010<\mathrm{t}$-count $<2.010$, it means Ho "received" or Ha "rejected". Based on the calculated value of $\mathrm{t}$-count $=1,233$ and $\mathrm{t}$-table $=2.010$ or $\mathrm{t}$-count $>\mathrm{t}$-table, and $\mathrm{Sig}<0.05$ this means Ho "accepted" or Ha "rejected"

c. The normal curve of partial hypothesis testing

Figure

Normal Curve of Partial Hypothesis Test

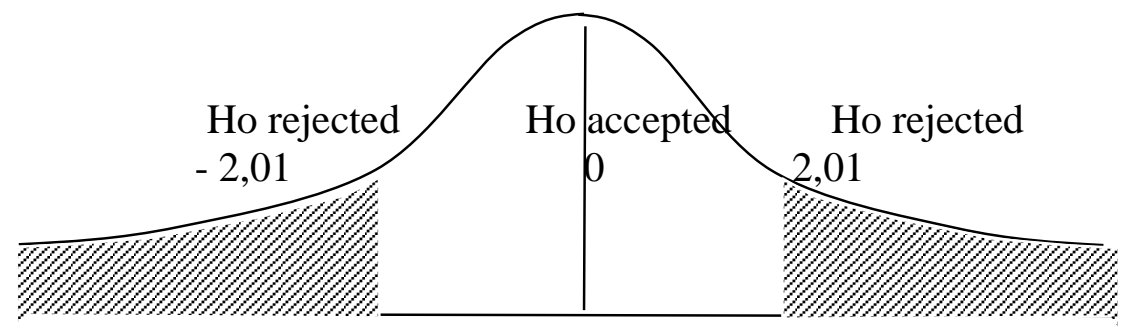

d. Discussion 
With the acceptance of the hypothesis Zero (Ho) and the rejection of alternative hypothesis (Ha), then the partial leadership variable (X1) has no significant effect on employee performance (Y) national unity of government of Sorong regency.

\section{Test the influence of motivation factors on employee's work achievement}

a. Formulate statistical hypothesis

Ho: $b_{1}=0, \quad$ it means that the motivation factor partially has no effect on the work achievement of the employee of National Unity Board of government of Sorong Regency.

Ha: $b_{1} \neq 0$, it means that motivation factors partially affect the work performance of employees of the National Unity Board of government of Sorong Regency.

b. Determination of critical $t$ value

The critical value $\mathrm{t}(\alpha, \mathrm{n}-\mathrm{k})$ where $\mathrm{k}=3$ and $\mathrm{n}=50$, and $\alpha=5 \%$, then $\mathrm{t}(0.025,47)=2.010$. If $-2,010<\mathrm{t}$-count $<2.010$, it means Ho "received" or Ha "rejected". Based on the calculation of the value of $\mathrm{t}$-count $=18.745$ and $\mathrm{t}$-table $=2.010$ or $\mathrm{t}$-count $>\mathrm{t}$-table, it means Ho "rejected" or Ha "received"

c. Normal Curve of partial hhypothesis testing

Figure

Normal Curve of Partial Hypothesis Test

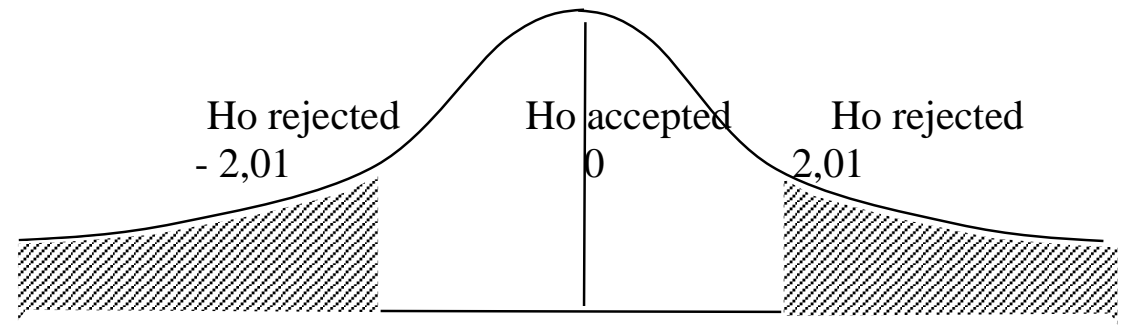

c. Discussion

With the rejection of the Hypothesis Zero (Ho) and the acceptance of Alternative Hypothesis (Ha), it is proven that the partial variable Motivation (X2) significantly affects the performance of employee (Y) the national unity of government of Sorong regency. Motivation are given to employees will bring the effect of increasing employee achievement because they feel rewarded extrinsically.

\section{The influence test of disciplinary factors toward employees' work achievement}

a. Formulating the Statistical hypothesis

Ho: $b_{1}=0$, it means that the discipline factor partially has no effect on the work achievement of the employees of the National Unity Board of government Sorong Regency. 
Ha: $b_{1} \neq 0$, it means that the discipline factor partially affects the work achievement of employees of the National Unity Board of government of Sorong Regency.

b. Determination of the critical $t$ value

The critical value $\mathrm{t}(\alpha, \mathrm{n}-\mathrm{k})$ where $\mathrm{k}=3$ and $\mathrm{n}=50$, and $\alpha=5 \%$, then $\mathrm{t}(0.025,47)=2.010$. If - 2,010 <t-count <2.010, it means Ho "received" or Ha "rejected". Based on the calculation of $\mathrm{t}$-count value $=-2.29$ and $\mathrm{t}$-table $=2.010$ or $\mathrm{t}$-count $>\mathrm{t}$-table, it means Ho "rejected" or Ha "received"

c. Normaal curve of partial hypotheis test

The normal partial hypothesis test curve can be presented in the following figure:

Figure

Normal Curve of Partial Hypothesis Test

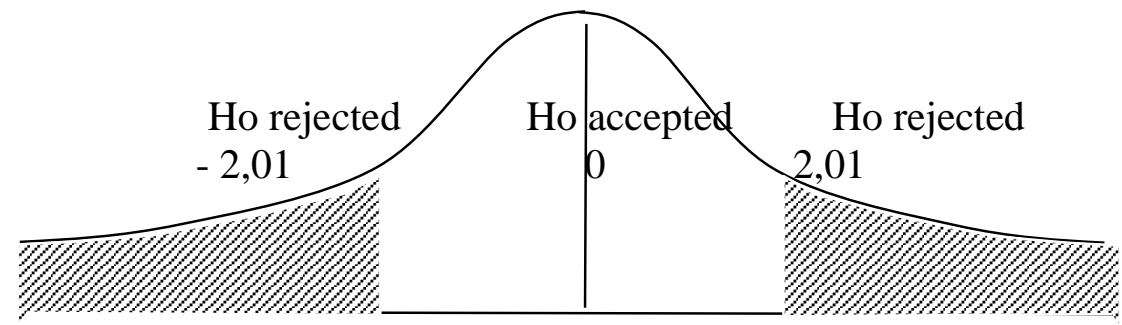

\section{d. Discussion}

With the rejection of Hypothesis Zero (Ho) and acceptance of Alternative Hypothesis (Ha), it is proved that the partial variable Discipline (X3) significantly affects toward employees' work achievement (Y) Sorong Unitary State Government. On the basis of the results of these analyzes showed that employees' work achievement will increase if balanced also improvements in work discipline because it will feel getting attention through the discipline that will ultimately affect the increased employees' work achievement.

\section{Verification and discussion the third hypothesis}

In accordance with the third hypothesis is that among the factors of leadership, motivation, discipline, is the dominant factor of motivation affecting the work performance of the employees of the National Unity Board of Government of Sorong Regency, then to test the significance of the hypothesis is based on the contribution of each independent variable indicated through the amount partial determinant coefficient (r12).

a. Test dominant factor

From result of calculation of coefficient correlation (ri) obtained value as follows:

Table

Results of Partial Determination Calculations among Independent Variables 


\begin{tabular}{|c|l|c|c|c|}
\hline No. & \multicolumn{1}{|c|}{ Variable } & Partial correlation & Partial Determination & Conclusion \\
\hline 1 & Leadership & 0,179 & 0,061 & \\
\hline 2 & Motivation & 0,940 & 0,931 & Dominant \\
\hline 3 & Discipline &,- 320 & $-1,114$ & \\
\hline
\end{tabular}

From the calculation result of partial determination as in the above table shows that the rise of the performance of employee performance, partially contributed by leadership factor $17,9 \%$, motivation factor $94 \%$ and discipline factor $-32 \%$. This shows that partially successive factors affecting employee performance are started from leadership, discipline and motivation, and thus motivation factor becomes the dominant factor in influencing employees' work achievement.

From the results of the analysis above, the third hypothesis is between the factors of leadership, motivation, and discipline dominant toward motivation factor influence on the work performance of the employees of the National Unity Board of government of Sorong regency has been proven.

\section{H. Conclusion}

According to the results of research between the factors of leadership, motivation and discipline, motivational factors dominant influence on the performance of employees of the Unity Board of the government of Sorong Regency. Motivation is defined as the state and mental attitude of human beings who provide energy, drive activities or movements and direct or channel the behavior towards the achievement of needs that provide satisfaction or reduce imbalances. Thus, motivation is a powerful impetus that one desires to do something to fulfill a need.

\section{BIBLIOGRAPHY}

Bernadin dan Russel, 1997. Manajemen Sumber Daya Manusia. Bandung: PT. Armico. 
Dwiyanto, Agus 1995, Penilaian Kinerja Organisasi Pelayanan Publik, Yogyakarta : Fisip UGM.

Edwin B. Flippo. 2002. Manajemen Personalia. Jakarta: Erlangga.

Effendy, Onong, Uchjana. 1986. Dinamika Dimensi Komunikasi. Jakarta: Rosda Karya.

Henry, Simamora. 2001. Manajemen Sumber Daya Manusia (Edisi 3). Yogyakarta: STIE YKPN.

Herzberg, F. 1987. One more time: how do you motivate employees? Harvard Business Review 46(1), pp. 53-62.

Kartono. Kartini. 1998. Pemimpin dan Kepemimpinan .Jakarta:PT. Grafindo Persada.

Malayu, S. Hasibuan. 2002. Manajemen Sumber Daya Manusia. Jakarta: Bumi Aksara.

Maslow, Abraham. 1987. Motivation and personality. New York: Harper and Row.

Moekijat. 1999. Manajemen sumber daya manusia : manajemen kepegawaian. Bandung : Mandar Maju.

Pearson. 1994. Explicit Comprehension Instruction: A Review of Research and a New Conceptualization of Instruction.” Elementary School Journal, No. 2: pp. 151165.

Siagian, Sondang P. 1983. Manajemen Sumber Daya Manusia. Jakarta : Bumi Aksara.

Salusu, J., 1996, Pengambilan Keputusan Stratejik, Untuk Organisasi Publik dan Organisasi Nonprofit. Jakarta: PT Gramedia Widiasarana Indonesia.

Sumedi. 1985. Organisasi Kepemimpinan dan perilaku Administrasi, Jakarta:Gunung Agung.

Sedarmayanti. 2001. Sumber Daya Manusia Dan Produktivitas Kerja. Bandung : Mandar Maju.

Tjokroamidjojo, Bintoro. 1985. Efesiensi Nasional dalam manajemen pembangunan. Jakarta: Departemen Dalam Negeri RI.

Thoha, Miftah, Mohamad. 1993. Kepemimpinan dalam Manajemen Suatu Pendekatan Prilaku. Jakarta: PT.Raja Grafindo Persada.

Wahyudi, Pantja, Sunjata. 1997. Kupatan Jalasutera Tradisi (Makna dan Simboliknya). Yogyakarta: Depdikbud. 